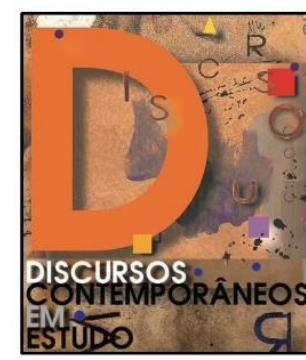

\title{
MEMETÁFORA: ANÁLISE DO PAPEL DAS METÁFORAS MEMÉTICAS NA LUTA DE CLASSE
}

\author{
Alexandre Tolentino de Carvalho (UnB $)^{1}$
}

O objetivo desse trabalho é analisar os memes sobre a Greve Geral do dia 28 de abril de 2017, buscando configurar o papel atribuído a eles na construção da luta de classes. Assim, identificamos os mapas conceituais metafóricos utilizados na construção dos memes e os categorizamos conforme as escolhas metafóricas e conforme os objetivos pretendidos por seus autores. Para tanto, utilizamos a Teoria da Metáfora Conceitual de Lakoff e Johnson e o enfoque da Análise de Discurso Crítica para análise dos dados. Os dados demonstraram a existência de dois grupos antagônicos que apresentaram mapas conceituais metafóricos bastante similares intragrupo e muito opostos intergrupo, marcando bem as diferenças de escolhas realizadas e de objetivos pretendidos. Os memes coxinhas denotaram conteúdo nitidamente partidarista, tendentes a desmobilizar a luta e macular a imagem de determinado partido e os memes mortadelas apresentaram conteúdo classista tendente a mobilizar os trabalhadores para a resistência. Concluímos que o estudo dos memes pode ajudar a levantar pistas para subsidiar a compreensão dos fenômenos sociais.

Palavras-chave: memes; metáforas; luta de classe; discurso.

The aim of this study is to analyze the memes on the General Strike of day 28 April 2017 seeking to set up the role assigned to them in the construction of the class struggle. Thus, we identify the metaphorical conceptual maps used in the construction of memes and categorize them according to the metaphorical choices and according to the objectives intended by their authors. To do so, we use the theory of Conceptual Metaphors of Lakoff and Johnson and the focus of the critical analysis of the discourse for data analysis. The data demonstrated the existence of two antagonistic groups that presented very similar metaphorical conceptual maps intragroup and very opposite intergroup, marking well the differences of realized choices and of intended objectives. The "memes coxinhas" denoted clearly partisan content tending to demobilize the struggle and maculate the image of a particular party, and the "memes mortadelas" memes presented classist content tending to mobilize workers for resistance. We conclude that the study of memes can help to raise clues to support the understanding of social phenomena.

Keywords: memes; metaphors; class struggle; discourse.

\footnotetext{
${ }_{1}^{1}$ Doutorando pelo Programa de Pós-Graduação da Faculdade de Educação da Universidade de Brasília em 2018. Professor da Secretaria de Educação do Distrito Federal e membro do Grupo de Pesquisa e Investigação em Educação Matemática (CNPq) em 2018. Pesquisa criatividade em matemática e estuda criatividade compartilhada.
} 


\section{Introdução}

É nítido o fato de que nosso país vive uma conjuntura bastante atribulada que muito se assemelha a uma guerra civil. Tomando como recordação as últimas manifestações populares, podemos relembrar como a polícia vem repreendendo os manifestantes com bombas de efeito moral, e inclusive armas de fogo. Em contrapartida, alguns manifestantes reagem utilizando o que encontram à disposição como forma de defesa. Por isso, utilizando uma metáfora bélica, podemos dizer que a cada dia acontece uma batalha diferente cujo prêmio em disputa é o comando do cenário político.

Nessa batalha, assistimos ao delineamento de duas frentes antagônicas que travam pelejas constantes nos tribunais, nas tribunas parlamentares e nos canais midiáticos, como a televisão, o rádio e a internet. De um lado, podemos presenciar uma frente conservadora, representada por defensores das classes mais abastadas como os empresários, os militares de alta patente e os proprietários de grandes fortunas. Esses temem os avanços de direitos trabalhistas que podem causar a queda dos lucros e comprometer o domínio econômico que exercem sobre a sociedade em geral. De outro, do fronte, encontramos partidos políticos de esquerda e entidades de classes representadas por frentes populares, por sindicatos e centrais sindicais e por movimentos sociais. Essa frente almeja realizar uma coalizão com todos aqueles que se sentem ameaçados pelas ofensivas conservadoras e resistir aos ataques empreendidos contra os direitos sociais conquistados nas últimas décadas.

Nosso trabalho insere-se no meio desse campo de guerra em busca de tentar desvelar como tal confronto civil ocorre (pelo menos no campo das ideias) no sentido de buscar compreender que conceitos são defendidos sobre as lutas de classe. Para tanto, decidimos buscar dados em uma das armas mais utilizadas no que se refere aos duelos travados para a construção da opinião pública: a internet. E entre as várias formas de artifícios utilizados para convencer a sociedade, escolhemos analisar os memes, recursos em voga nas redes sociais.

Portanto, decidimos analisar os memes sobre a Greve Geral do dia 28 de abril de 2017, objetivando configurar o papel atribuído a eles na construção da luta de classes. Para tanto, buscamos:

a) Identificar os mapas conceituais metafóricos utilizados na construção dos memes; 
b) Categorizar os memes conforme as escolhas metafóricas e conforme os objetivos pretendidos.

Ao optar por um recorte como a Greve Geral, não escolhemos um momento aleatório da rica história de luta de classes do nosso país. Nem focamos em um momento cristalizado dessa história. A escolha por esse fato histórico se mostra bastante emblemática por se traduzir em uma atividade largamente discutida e organizada por um amplo conjunto de entidades classistas, sobretudo após a classe operária passar por ameaças concretas aos direitos trabalhistas e sociais conquistados arduamente por uma luta que se trava desde a invasão portuguesa às terras de Pindorama ${ }^{2}$. Portanto, a escolha por esse recorte da luta de classes se dá de forma proposital e em um movimento histórico dinâmico que não se encerra com o fim da greve, mas que prepara novos capítulos ainda inimagináveis.

\section{Aportes teóricos}

A seguir, apresentaremos os aportes teóricos que estruturam cada constructo presente em nossa pesquisa. É dessa forma que iremos abordar primeiramente a teoria sobre metáforas, trazendo algumas categorizações que serão úteis no momento de análise dos dados. Em seguida, apresentaremos alguns conceitos teóricos sobre a memética e sobre os memes que são os recortes discursivos componentes de nosso eixo de estudo.

\section{Metáforas}

As metáforas têm fornecido muitos elementos para a Análise de Discurso Crítica, uma vez que estão presentes tanto no sistema conceitual extraordinário, existente em situações discursivas não corriqueiras, tais como a poesia, em discursos oficiais ou em textos noticiosos, quanto no nosso sistema conceitual ordinário expresso por meio da linguagem em nossas ações discursivas cotidianas (LAKOFF; JHONSON, 1980). Alguns autores (por exemplo, FAIRCLOUGH, 2001; LAKOFF; JHONSON, 2002) evidenciam a naturalização dos conceitos metafóricos em nossos pensamentos e ações, de modo que,

\footnotetext{
${ }^{2}$ Nome atribuído ao Brasil pelos nativos antes da chegada dos portugueses.
} 
na maioria das situações, essas metáforas são utilizadas de forma inconsciente. Assim, elas penetram e se fixam em nossos pensamentos constituindo nossos discursos e indiciando o modo como nos posicionamos no mundo.

Alguns autores a consideram como uma parte essencial da estruturação do discurso (SILVA, 2006). Por exemplo, Van Dijk (2012) avalia as metáforas conceituais como uma fonte importante para a construção do mundo participando como um fator de condicionamento contextual. Assim, para o autor, as metáforas tanto constroem conceitos muito gerais quanto constroem e indiciam a cultura. Fairclough (2001) as considera como elemento estruturante de nosso pensamento e de nossa ação de maneira que a escolha por um tipo de metáfora em detrimento de outros tipos pode revelar o modo como construímos nossa realidade.

Os estudos mais proeminentes em relação às metáforas podem ser atribuídos à Lakoff e Johnson $(1980,2002)$ sendo os autores mais citados em relação a esse tema, o que permite considerar sua obra como um clássico. Em nossas análises, levamos em conta essa proeminência e iremos utilizar seus aportes teóricos e as categorizações que realizam sobre os tipos de metáforas para guiar a consecução de nossos objetivos de pesquisa.

Nascida no seio de um contexto de mudança epistemológica, provocada pela psicologia cognitiva ${ }^{3}$, a Teoria da Metáfora Conceitual (LAKOFF; JOHNSON, 1980) apresenta um novo paradigma para as metáforas, definindo-as como formas de entender e de experienciar um tipo de coisa em termos de outra ou de estruturar um conceito metaforicamente em termos de outro. Os autores apresentaram um conceito que caminhava junto à mudança paradigmática em curso nos anos de 1970, permitindo deslocar as metáforas de uma posição inferior de mera figura de retórica, na qual eram consideradas apenas como um desvio de linguagem ou um recurso poético e persuasivo e que precisava ser evitado na linguagem objetiva (LAKOFF, 1986), para evidenciar seu valor cognitivo, sendo compreendidas como recurso de construção mental e de representação da realidade.

\footnotetext{
${ }^{3} \mathrm{Na}$ Apresentação à Edição Brasileira do livro Metaphors we live by, de Lakoff e Johnson, traduzido para o português com o título "Metáforas da vida cotidiana", os organizadores se debruçam em um esforço de evidenciar o contexto no qual a obra surgiu. Assim, aponta-se o fato de que, na década de 1970, a psicologia cognitiva e a linguística propuseram a superação do enfoque objetivista das metáforas que parecia inquestionável há dois milênios e defenderam a construção do enfoque relativista. No novo paradigma, passa-se

a reconhecer o valor das metáforas, mudando do status de uma simples figura de retórica para o de uma operação cognitiva fundamental. Para mais informações a respeito da virada paradigmática, consultar a obra na íntegra.
} 
Desse modo, Lakoff e Johnson (1980) propõem uma teoria que supera a visão realista das metáforas, projetando-as como meio de acessar uma realidade e explicar situações complexas que, de outro modo, não seria possível. Nessa lógica, as metáforas são compreendidas como um sistema conceitual, revelado por meio da linguagem, que influencia nosso pensamento e nossa ação.

Os autores enriquecem seus argumentos com variados exemplos e partem do pressuposto de que as metáforas permeiam nosso cotidiano e constituem nosso pensamento e nossa linguagem, revelando as estruturas conceituais que nos permitem representar a realidade. Desse modo, ao apresentar as metáforas DISCUSSÃO É GUERRA e TEMPO É DINHEIRO, Lakoff e Johnson (2002) demonstram como esses conceitos metafóricos estão presentes no cotidiano, quando, por exemplo, afirma-se que a “oposição perdeu o debate” ou “não posso desperdiçar meu tempo".

Lakoff (1986) explica que as metáforas não são construídas por palavras ou expressões em particular, mas por mapeamentos ontológicos e epistêmicos (estruturados sistematicamente) de um domínio alvo com correspondência a um domínio fonte, estruturados sistematicamente da seguinte maneira: DOMÍNIO ALVO É DOMÍNIO FONTE. Assim, na metáfora AMOR É VIAGEM, por exemplo, o uso de domínios conceituais da semântica relativa ao domínio origem “viagem”, nos leva a compreender uma entidade complexa e abstrata como o domínio alvo "amor" ao recorrermos às estruturas semânticas menos abstratas observáveis no domínio "viagem”.

Desse modo, dizemos que "estamos nas nuvens" para expressar a intensidade de um amor ou "nossa relação não vai chegar a lugar algum" para demonstrar uma forma de amor problemática. Lakoff (1986) lembra que não é "apenas uma maneira de falar sobre amores como uma viagem, mas uma maneira de pensar sobre isso dessa maneira e de raciocinar com base em metáfora" (p. 216). Essa escolha se dá para representar as relações amorosas em termos de durabilidade, proximidade, dificuldades e objetivos comuns, características emprestadas do campo semântico do domínio “viagem”.

Os amantes correspondem aos viajantes, a relação amorosa corresponde ao veículo, estar se relacionando corresponde à proximidade física de viajar no mesmo veículo, os objetivos comuns dos amantes correspondem ao seu destino comum de viagem, as dificuldades amorosas correspondem aos problemas possíveis de ocorrer nas jornadas. Com isso, o autor busca romper com um dogma existente há dois milênios que sustenta que as metáforas são figuras de linguagem utilizadas em casos especiais de poética e retórica passando a encará-las como constituintes de nossos sistemas conceituais ordinários expressos no dia a dia o que nos permite raciocinar sobre um 
domínio (amor, tempo, discussão) com base em mapas conceituais pertencentes a outro domínio (viagem, dinheiro, guerra).

Essa compreensão das metáforas como parte de nosso sistema conceitual presente em no pensamento e expresso em na linguagem nos permitirá analisar a visão sobre a luta de classes que emerge dos mapas conceituais aos quais recorrem pessoas posicionadas em escolhas políticas e sociais antagônicas. Será dessa forma que iremos buscar as pistas que levam as pessoas a optarem por uma determinada maneira de representar as lutas de classe por meio de metáforas e desvelar o aparato cognitivo por detrás dessa escolha, utilizado para atingir os objetivos que almeja alcançar. Assim, percebemos que, ao optarem por representar as manifestações sociais recorrendo à metáfora MANIFESTAÇÃO É CAOS, por exemplo, pessoas posicionadas em classes sociais hegemônicas recorrem ao campo conceitual "caos" para desqualificar qualquer forma de reação das classes subalternas, buscando persuadir a opinião pública para qualificar qualquer forma de reação social como fruto da irresponsabilidade de quem se manifesta.

\section{Categorização das metáforas}

Lakoff e Johnson (2002) apresentam certa tipificação das metáforas que será muito útil em nossas análises. Assim, recorreremos a três categorias apresentadas pelos autores: metáforas orientacionais, metáforas ontológicas e metáforas estruturais.

\section{Metáforas Orientacionais}

Os autores as definem como conceitos metafóricos que organizam um sistema completo de conceitos em relação a outro. Sua nomenclatura se deve ao fato de que esse tipo de metáfora fornece uma orientação espacial aos conceitos, como quando se diz que "essa notícia me deixou para baixo", construindo-se um mapa conceitual no qual FELIZ É PARA CIMA e TRISTE É PARA BAIXO. As metáforas orientacionais buscam relação com o corpo humano e o espaço que ocupa, uma vez que a musculatura, como a do rosto, de quem se encontra feliz tende a se orientar para cima e ocorrer o contrário quando se está triste, o que permite aos autores concluir que "essas orientações espaciais surgem do fato de termos os corpos que temos e do fato de eles funcionarem 
da maneira em que funcionam no nosso ambiente físico" (LAKOFF e JOHNSON, 2002, p. 59).

No entanto, além de se basearem em nossas experiências físicas, as metáforas orientacionais também se apoiam em nossas experiências culturais de forma coerente, o que permite a uma metáfora ter significados diversos em culturas também diversas. Desse modo, as metáforas orientacionais não surgem no vácuo, mas se estruturam coerentemente em experiências físicas e culturais.

\section{Metáforas Ontológicas}

Fornecem subsídios para que possamos compreender entidades abstratas em termos de objetos físicos (sobretudo em termos do corpo humano), como quando o Senador Paulo Rocha afirma que "a crise instalada no Brasil foi provocada por uma 'conspiração política' que culminou com o impeachment da ex-presidente Dilma Rousseff"4. Ao afirmar que a crise foi instalada, o Senador toma uma entidade abstrata como um objeto físico sujeito a ser instalado para representá-la não como resultado do mercado ou dos problemas políticos, mas como algo intencionalmente produzido para desestabilizar o Governo. Para Lakoff e Johnson (2002):

Da mesma forma que as experiências básicas das orientações espaciais humanas dão origem às metáforas orientacionais, as nossas experiências com objetos físicos (especialmente com nossos corpos) fornecem a base para uma variedade extremamente ampla de metáforas ontológicas, isto é, de formas de se conceber eventos, atividades, emoções, ideias, etc. como entidades e substâncias (LAKOFF; JOHNSON, 2002, p. 76).

Ao tomar tais ideias abstratas em termos de objetos físicos, podemos nos referir às nossas experiências, categorizá-las, qualificá-las, quantificá-las, identificar aspectos particulares e compreendê-las. Assim, essa tentativa de minimizar os sentidos abstratos nos permite lidar com nossas experiências buscando compreender e convencer os ouvintes a aceitarem nossa compreensão. Como exemplo, Lakoff e Johnson (2002) apresentam a metáfora A MENTE É UMA MÁQUINA presente em afirmações como “minha mente não está funcionando" ou "já estou um pouco enferrujado em relação à matemática”.

\footnotetext{
${ }^{4}$ Discurso do Senador Paulo Rocha (PT-AL) na plenária do Senado Federal do dia 18 de maio de 2017.
} 
Como veremos a seguir, alguns tipos especiais de metáforas ontológicas foram identificadas em nossas análises. Portanto, é interessante realizar ainda breves comentários sobre a personificação e a metonímia.

\section{Personificação}

São metáforas utilizadas para se referir a objetos físicos e entidades não humanas como pessoas. Esse recurso permite “compreender uma grande variedade de experiências concernentes a entidades não humanas em termos de motivações, características e atividades humanas" (LAKOFF e JOHNSON, 2002, p. 87). Logo, na construção "a inveja mata” vemos a atribuição de uma atividade humana (matar) a uma entidade não humana (inveja). Aqui, o mapa conceitual INVEJA É PESSOA, PESSOAS MATAM, INVEJA MATA nos leva a construir a personificação da inveja como algo que pode resultar em morte, permitindo-nos atribuir sentidos sobre alguns casos de pessoas que, tomadas pelo sentimento de inveja, chegaram ao ponto de assassinar suas vítimas invejadas.

\section{Metonímia}

Esses são casos de metáforas em que se usa uma entidade para se referir a outra a ela relacionada. Quando, por exemplo, na figura 1 apresenta-se a ilustração de árvores, representando os pulmões humanos, temos as metáforas RESPIRAÇÃO É PULMÃO e ÁRVORE É RESPIRAÇÃO. Essas duas metáforas são exemplos de metonímias na medida em que "pulmões" são usados para se referir a todo um sistema respiratório e na medida em que "árvores" são utilizadas como se fossem órgãos componentes do sistema respiratório. 
Figura 1 - Metonímia da respiração

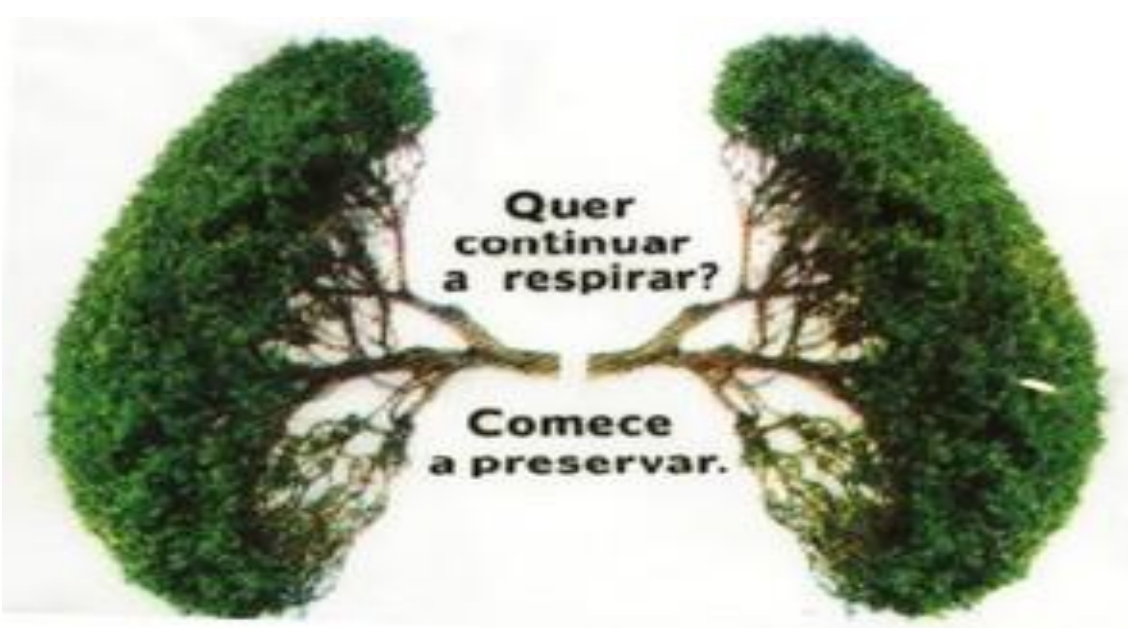

Fonte: Google Imagens.

Lakoff e Johnson (2002) evidenciam uma diferenciação entre metáforas e metonímia, salientando a importância das metonímias na medida em que permitem focalizar, de forma mais específica, certos aspectos da entidade a que se refere. Assim, em nosso exemplo anterior, a metonímia utilizada permite acentuar a importância da preservação para a continuidade da vida humana, construindo o silogismo: se VIVER É RESPIRAR, RESPIRAR É PRESERVAR, então, VIVER É PRESERVAR.

\section{Metáforas estruturais}

São tipos de metáforas que, além de realizar todas as funções daquelas do tipo orientacional e ontológico, como se referir a conceitos, quantificá-los etc, permitem "usar um conceito detalhadamente estruturado e delineado de maneira clara para estruturar outro conceito” (LAKOFF e JOHNSON, 2002, p. 134). Os autores apresentam como exemplo a metáfora DISCUSSÃO É GUERRA. Tal metáfora é constituída levando-se em consideração o fato de que, tanto na discussão quanto na guerra, são empregadas táticas de intimidação, de ameaça, de apelo à autoridade etc.

Mas, ao utilizar metáforas como "seus argumentos não são fortes o suficiente", um falante busca vencer seu interlocutor desqualificando seus argumentos e estruturando seu discurso por meio de conceitos metafóricos, tomados do campo semântico bélico, um campo semântico bem estruturado e presente no cotidiano cultural de muitas nações. Desse modo, o campo conceitual bélico permite construir uma compreensão mais concreta sobre uma entidade bastante abstrata como é a discussão. 
Outro exemplo de metáfora estrutural pode ser encontrado em Bento e Silva (2016). As autoras avaliaram um texto retirado da prova do ENEM 2014 que apresenta a imagem de um bicho papão para representar metaforicamente um mal real, a violência sexual. Assim, elas avaliam essa metáfora como estrutural na medida em que "há um conceito bem conhecido (medo de criaturas imaginárias, aqui representadas pelo monstro) para delinear outro (violência sexual)" (BENTO; SILVA, 2016, p. 135).

Em nossos achados, encontramos esses três tipos de metáforas nos memes analisados e percebemos como se dá o processo de construção cognitiva dos conceitos defendidos pelos discursos antagônicos acerca da luta de classes. Veremos que as escolhas metafóricas dão pistas claras de quem são, o que desejam, como agem e como pensam aqueles que as utilizam em seus discursos. Nesse sentido, podemos observar de fato aquilo que Lakoff e Johnson $(1980,2002)$ definem a respeito das metáforas: elas estão presentes no cotidiano estruturando não somente nossa linguagem, mas nosso pensamento e nossas ações.

\section{Memes: viralizando informações}

0 interesse pelos memes que circulam nas redes sociais nos foi despertado ao perceber como os principais acontecimentos políticos, sociais, econômicos e de toda espécie de ordem são acompanhados pela produção e pelo compartilhamento desse tipo de texto em uma velocidade e facilidade de propagação inimagináveis. No entanto, apesar de ter se popularizado na versão on-line, esse tipo textual faz parte de um campo teórico que já apresenta um histórico processo de consolidação.

Meme é um termo abreviado do grego mimema que significa imitação. 0 termo foi utilizado por Richard Dawkins, em seu livro “O gene egoísta”, que cunhou o termo para soar de forma aproximada à palavra gene. Desse modo, o autor intencionou intitular um replicador de informações culturais por meio de um substantivo que pudesse passar a ideia de uma unidade de transmissão cultural, assim como o gene representa uma unidade de transmissão genética.

Buscando aplicar conceitos da Teoria da Evolução à cultura humana, o autor apresenta um corpo de teoria social, baseando-se na seleção natural, dando origem à teoria da memética. É assim que Dawkins (1979) define o meme como uma unidade de informação com capacidade de se multiplicar por meio das ideias e das informações que 
se propagam de indivíduo para indivíduo. Fazendo alusão à seleção natural que ocorre pela reprodução diferencial não aleatória dos genes, o autor considera que a transmissão cultural é análoga à transmissão genética salientando que, mesmo que seja basicamente conservadora, pode originar um tipo de evolução (Dawkins, 1979). Porém, o autor enfatiza a grande diferença entre a evolução da língua e a evolução biológica: a primeira evolui por meios não genéticos e em uma velocidade bem superior à da segunda.

Assim como a linguagem, Dawkins (1979) afirma que a evolução cultural propiciada pela replicação de informações (com sua função ao mesmo tempo conservadora e transformadora) também ocorre em relação a outras áreas: na moda nos vestidos, na alimentação, nos costumes, na arte, na arquitetura e engenharia, na tecnologia etc. Nesse sentido, os memes estão presentes em todas as manifestações culturais e sociais e se propagam fácil e velozmente.

E aqui reside a necessidade de serem estudados. Uma vez que são responsáveis pela propagação de informações com funções contraditórias e complementares, permitindo tanto a conservação da cultura como também possibilitando o surgimento da criatividade, os memes constituem armas ideológicas poderosas tanto no sentido de manter o status quo quanto em relação à possibilidade de contrapor-se ao poder hegemônico. Em consonância com o poder ideológico dos memes, Dawkins (1979) lembra as considerações que um de seus colegas fez quando teve acesso às primeiras versões de seu livro:

os memes devem ser considerados como estruturas vivas, não apenas metafórica mas tecnicamente. Quando você planta um meme fértil em minha mente, você literalmente parasita meu cérebro, transformando-o num veículo para a propagação do meme, exatamente como um vírus pode parasitar o mecanismo genético de uma célula hospedeira. $E$ isto não é apenas uma maneira de falar - o meme, por exemplo, para "crença numa vida após a morte" é, de fato, realizado fisicamente, milhões de vezes, como uma estrutura nos sistemas nervosos dos homens, individualmente, por todo o mundo (DAWKINS, 1979, p. 122-123).

0 recorte de memes que escolhemos analisar diz respeito a textos multimodais veiculados nas redes sociais. Esse tipo de meme começou a tomar forma em 1998 principalmente a partir da fundação do Weblog Memepool, no qual eram disponibilizados links para conteúdos com estilo sarcástico.

$\mathrm{Na}$ atualidade, vemos a replicação de informações ocorrer de forma acelerada, o que passa a ser denominado como viralização. Talvez por se mostrar como uma linguagem acessível e tendente a provocar o humor, passa despercebido pelas pessoas 
comuns o potencial ideológico por detrás dos memes, sobretudo por se constituir em um meio poderoso de propagar ideologias e agir fortemente na formação de opinião da grande massa da população, persuadindo as pessoas a comprar brigas a assumir lados polarizados e antagônicos. Desse modo, as pessoas são convencidas a optarem por determinada forma de compreender os acontecimentos políticos, sociais, religiosos e econômicos, principalmente ao ser utilizada uma linguagem metafórica, o que permite explicar os fatos sociais de forma acessível para uma grande quantidade de pessoas.

Portanto, o meme pode muito bem ser considerado como uma forma de discurso ideologicamente orientado, tal como Fairclough (2001) concebe em sua Teoria Social do Discurso. Assim, o meme, como discurso ideológico, permite aos seus autores construir uma realidade que pode tanto cooperar para a produção e para a reprodução das relações de dominação, quanto pode contribuir para sua transformação e superação.

No entanto é preciso salientar, assim como percebemos ao analisar os memes sobre lutas de classe, que um fator é importante para que o meme se replique: as pessoas precisam compartilhar um conhecimento mínimo sobre o tema tratado. Isso implica que o fator cognitivo apresenta bastante relevância para a compreensão das informações contidas no meme, sendo que tal compreensão pode se dar em um ciclo cultural, mas não em outros. Por exemplo, o meme da figura 2 faz sentido para boa parte dos brasileiros, mas outras culturas, como estrangeiros que não acompanham os acontecimentos políticos internacionais ou mesmo brasileiros sem acesso aos meios de comunicação, podem não compreender as informações implícitas contidas no texto. De fato, a metáfora IMPEACHMENT É CINEMA passa a construir um mapa conceitual que permite à audiência concluir que um instrumento político, que deveria ser utilizado em casos extremos, tem sido banalizado. No entanto, para construir esse mapa conceitual é preciso compreender minimamente o cenário político nacional atual, ou seja, ter conhecimentos compartilhados com o produtor do meme, o que chamamos de cognição compartilhada (CANNON-BOWERA; SALAS, 2001). 
Figura 2 - Meme sobre impeachment

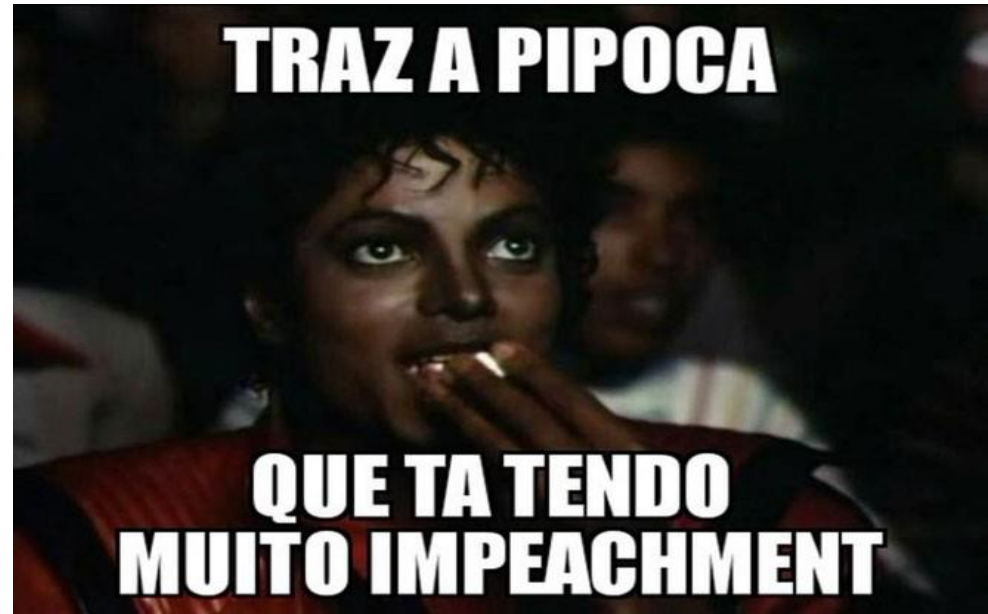

Fonte: Google Imagens.

É interessante notar que os memes constroem julgamentos por meio de metáforas conceituais. Portanto, em nosso estudo, a análise desses conceitos metafóricos nos permitiu compreender como e com quais objetivos pessoas de posicionamentos sociais e políticos antagônicos constroem e divulgam determinada compreensão da realidade, nomeadamente a compreensão sobre a Greve Geral. Em nossos estudos, chamamos os textos de metáforas meméticas (ou memetáforas) para demarcar o valor metafórico dos memes. A seguir, apontamos a metodologia de pesquisa para em seguida apresentar as análises e as conclusões realizadas.

Análise de metáforas meméticas sobre a luta de classes

Recorrendo à Teoria da Metáfora Conceitual de Lakoff e Johnson (1980, 2002) e a Teoria Social do Discurso (FAIRCLOUGH, 2001), analisamos memes veiculados no contexto da Greve Geral que ocorreu no dia 28 de maio de 2017. De tal forma, as análises seguiram o conceito de mapas metafóricos conceituais (LAKOFF e JOHNSON, 2002) e se guiaram pela concepção tridimensional do discurso apresentado por Fairclough (2001) em que se deve atentar à análise do texto, das práticas discursivas e das práticas sociais. Escolhemos esse recorte por ser um momento ícone para a luta de classes por razões justificadas a seguir. O período de2016/2017 ficará marcado como aquele em que o cenário político e social esteve no "olho do furacão", para utilizar uma metáfora que possa representar o turbilhão de acontecimentos ocorridos em tão pouco tempo. Passamos por uma avalanche de denúncias de corrupção, pelo segundo 
impeachment da história do Brasil, por reformas antipopulares que representaram e ainda representam ataques aos direitos sociais e trabalhistas até então consolidados.

Todos esses fatos levaram à desestabilização de uma aparente ordem social que se desenhava no decorrer da última década após a eleição em 2002 de um Presidente esquerdista e extremamente popular. Marcada por avanços sociais no que diz direito à distribuição de renda e à consolidação de ganhos trabalhistas, essa década de Governo esquerdista, no entanto, passou a incomodar setores empresariais e conservadores que começaram a se sentir ameaçados pelas conquistas sociais. Esse setor começa, assim, a exigir uma nova agenda de reformas que modificassem o ensino, as leis trabalhistas, as relações empregador-empregado e as leis previdenciárias. O Governo pós-impeachment, então, dá início a implementação de uma política de austeridade que provoca a reação da classe trabalhadora por meio das entidades de classe.

É nesse contexto de luta entre duas classes opostas que se desenhou a Greve Geral de 2017, sendo marcada para ocorrer no aniversário de cem anos da primeira Greve Geral do país. 0 manifesto foi organizado por várias entidades que representavam mais de dez milhões de trabalhadores, como a Central Sindical Popular (CSP), a Força Sindical, o Movimento dos Trabalhadores Rurais Sem Terra, a Central Única dos Trabalhadores, a Frente Nacional de Mobilização Povo Sem Medo, entre outras. No entanto, como constataremos nas análises a seguir, somente uma dessas entidades é apontada como a responsável por uma ação avaliada pela classe conservadora e empresarial como fracassada e causadora de transtornos para a sociedade.

\section{A análise das memetáforas}

Ao pesquisar os memes existentes sobre a greve geral, encontramos um apanhado de postagens que podem ser categorizadas em dois grupos: um grupo contrário ao manifesto e outro grupo favorável. Nenhuma postagem apresentou meio termo, o que nos levou a concluir que, nesse caso, existem dois grupos antagônicos bem definidos.

Nomeamos o primeiro grupo como “coxinhas", uma alusão a um termo bem propagado nas redes sociais e que se refere àqueles orientados para um perfil social e político conservador. O termo coxinha é usado de forma pejorativa por pessoas da esquerda para se referir aos pertencentes à burguesia e, portanto, interessados em manter o status quo indo contra qualquer ação que possa ameaçar a ordem social burguesa. Por isso, os coxinhas possuem aversão às políticas esquerdistas sentindo-se 
ameaçados pelos avanços sociais e trabalhistas que podem representar diminuição dos lucros das empresas ou mesmo constrangimentos ao ter que compartilhar bens com as classes subalternas antes restritos às classes altas.

O segundo grupo foi nomeado como "mortadela", um termo também pejorativo empregado por pessoas da direita para qualificar aqueles inclinados para as lutas esquerdistas. É uma alusão ao que dizem compor o lanche oferecido pelos partidos de esquerda aos militantes para que pudessem participar de manifestações. Assim, essa seria mais uma forma de desqualificar as lutas de classes, compondo o conceito de que as pessoas, pobres em sua maioria, não estariam envolvidas nas manifestações por interesses de classe, mas sim em troca de alimentação barata.

Em nossas análises, selecionamos cinco memes de cada uma dessas classificações, buscando a) categorizar o tipo de metáfora empregada, b) identificar as metáforas conceituais construídas e c) identificar os objetivos almejados com esses conceitos. Após realizar essas análises individualmente, procuramos sintetizar as informações empregadas em cada grupo de memes para configurar os conceitos que coxinhas e mortadelas constroem sobre a luta de classes.

\section{Memes coxinha}

O primeiro meme analisado apresenta a figura do personagem Willy Wonka do filme “A fantástica fábrica de chocolate”. Com um ar sarcástico e a apresentação de uma expressão facial que remete à desconfiança, o meme propõe questionar o fato de que a Greve Geral tenha sido marcada para a sexta-feira, 28 de abril, sendo que na segunda-feira, $1^{\circ}$ de maio, seria o feriado do dia do trabalhador. 
Figura 3 - Meme Coxinha 1 sobre Greve Geral

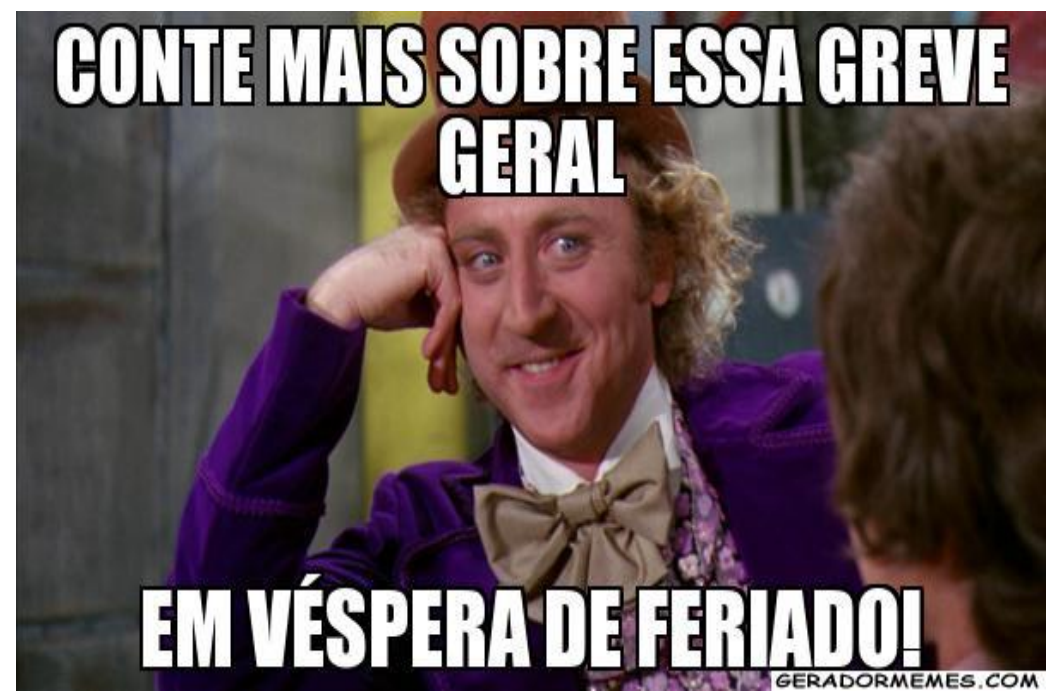

Fonte: GeradorMemes.com.

Categorizamos essa metáfora como orientacional, pois percebemos a nítida tentativa de desqualificar o movimento social, colocando-o para baixo na medida em que se julga que a greve tinha o propósito de estender o feriado. Portanto, percebemos a apresentação do conceito metafórico GREVE É VAGABUNDAGEM, um conceito que apareceu em muitos outros memes analisados. Os objetivos desse meme são depreciar a greve e desconstruir a resistência. Portanto, enfatiza-se a proximidade do evento com o feriado do dia dos trabalhadores e omite-se as informações do contexto como os ataques contra os direitos sociais promovidos pela implementação de reformas e pela escolha da data para representar o centenário da primeira greve geral do país.

O segundo meme analisado apresenta a imagem de policiais equipados com escudos e, no primeiro plano, pneus incendiados. A imagem omite a presença de qualquer ser humano como manifestante e, surpreendentemente, apresenta os pneus como os participantes, insinuando que algumas poucas pessoas (de uma entidade sindical em específico) provocaram o caos ao incendiar pneus em via pública. 
Figura 4 - Meme Coxinha 2 sobre Greve Geral

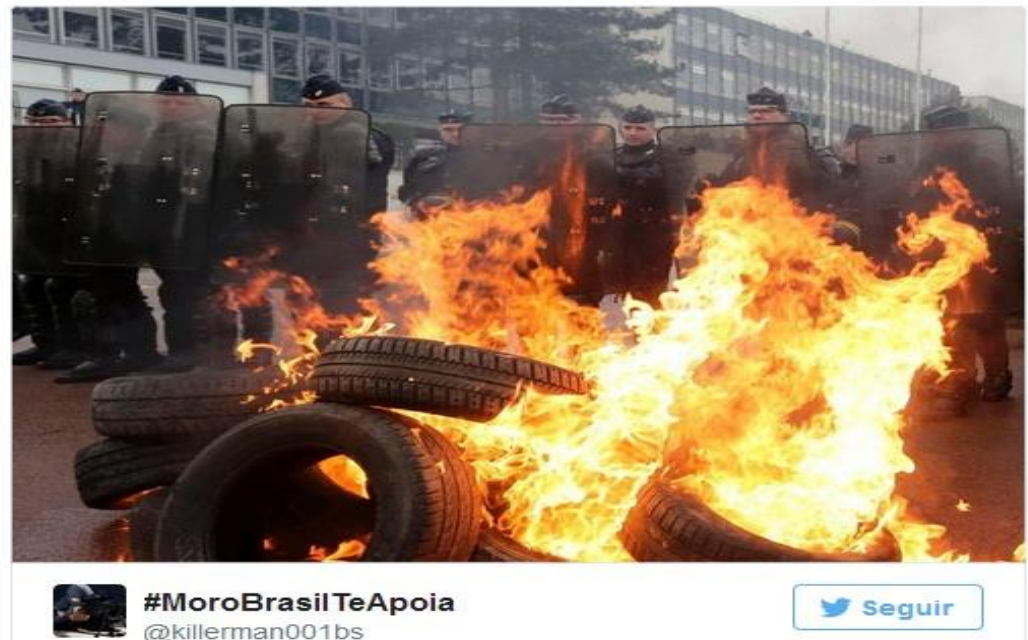

Até agora percebi um apoio maciço por parte dos pneus. Estão mobilizados em várias cidades... GAME OVER CUT! @crixtal7 \#AGreveFracassou

Fonte: Google Imagens.

Encontramos aqui metáforas orientacionais que posicionam o movimento para baixo por meio de recursos imagéticos e verbais (reforçando a ideia de derrota com o termo em letras garrafais 'GAME OVER CUT' e a hashtag AGreveFracassou). Também podemos identificar o uso de metáforas ontológicas na medida em que se refere aos manifestantes por meio dos pneus em chamas e na medida em que se refere à Central única dos Trabalhadores (CUT) como responsável única pela greve. Assim, presenciamos tanto a personificação dos pneus tomados em termos de entidades humanas quanto à metonímia parte/todo ao referenciar a CUT em meio a um conjunto amplo de entidades sociais responsáveis pela greve.

Nesse meme, identificamos o seguinte mapa metafórico conceitual: MANIFESTAÇÃO É CAOS, MANIFESTAÇÃO É CUT, GREVE É FRACASSO, CUT É FRACASSO. Com isso, o autor do meme objetiva depreciar a greve e desconstruir a resistência da classe trabalhadora aos ataques sofridos pela política de austeridade. Para tanto, as ofensas são direcionadas aos participantes da greve e, em maior proporção, à entidade que ganhou maior projeção com a eleição dos governos esquerdistas e passou a representar ameaça para as classes altas do país.

A próxima publicação analisada também se refere aos participantes da greve. No entanto, aqui se percebe um discurso mais ofensivo por meio de vários insultos. Primeiramente, ao apresentar a imagem de burros, ícones da falta de inteligência, 
comparando-os com os manifestantes, o autor tenta passar a ideia de que tais pessoas não têm consciência das motivações que os impulsionam a participar da greve. Ainda, pode-se perceber que a pouca quantidade de animais na pista contrasta com o texto irônico que afirma que diversas estradas foram bloqueadas pelos grevistas. Novamente aqui aparece a referência à CUT como responsável pela greve.

Figura 5 - Meme Coxinha 3 sobre Greve Geral

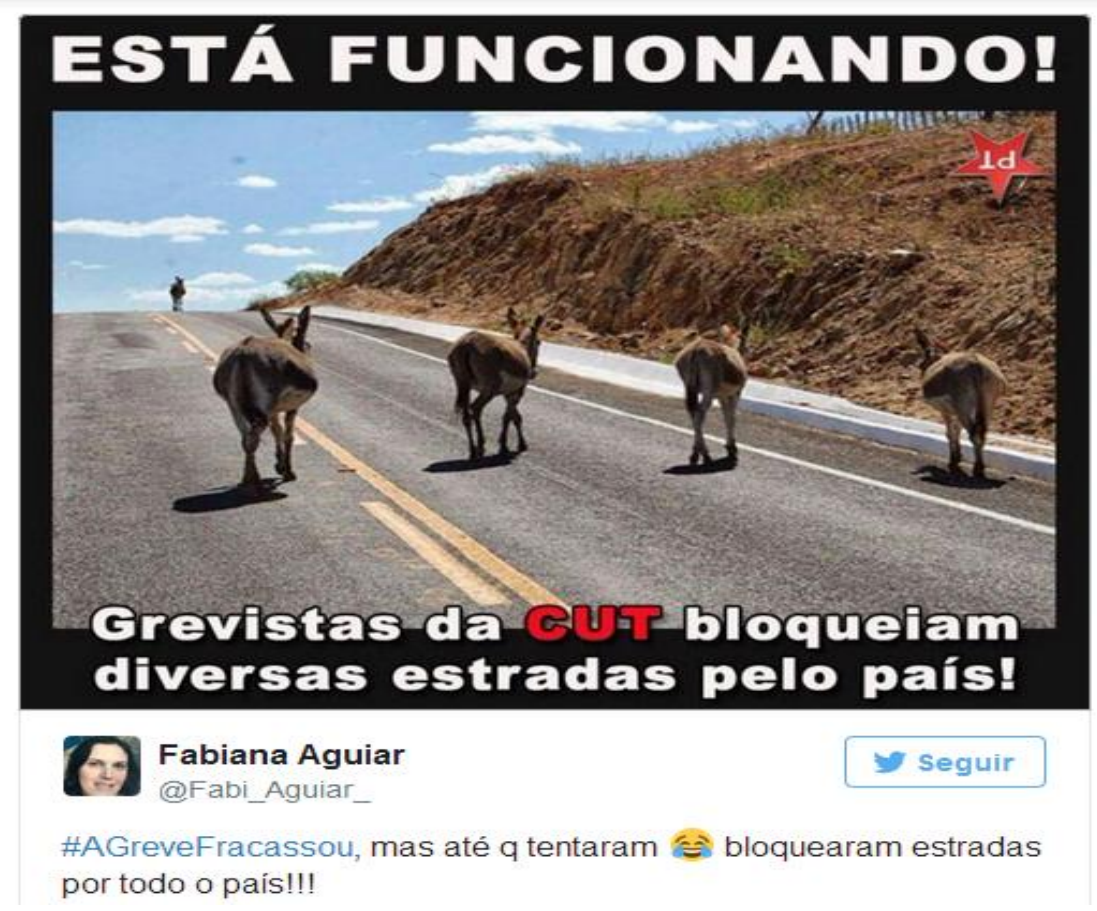

Fonte: Google Imagens.

A metáfora orientacional apresenta-se por meio de diversos recursos para posicionar a greve para baixo e desqualificar entidades representantes dos trabalhadores. Primeiramente, pode-se apontar a quantidade reduzida de elementos na pista representando a hipotética baixa adesão de manifestantes. Em seguida, pode-se perceber que esses elementos estão caminhando na contramão da via, passando a mensagem que a greve não é algo correto a se fazer. Outro recurso metafórico utilizado pode ser percebido na imagem da estrela do Partido dos Trabalhadores orientada para baixo como se estivesse caindo. Temos também metáforas ontológicas no sentido de que há a personificação dos animais tomados como manifestantes e, novamente, há a metonímia parte/todo quando o autor qualifica os manifestantes como "grevistas da CUT".

O mapa conceitual metafórico aqui presente é o seguinte: MANIFESTAÇÃO É CAOS, MANIFESTAÇÃO É CUT/PT, GREVE É FRACASSO, CUT/PT É FRACASSO, GREVISTA DA CUT É BURRO. O autor almeja, assim, dividir a classe trabalhadora na medida em que tenta 
convencê-los a não aderir a um movimento fracassado. Busca ainda depreciar a greve, criminalizar a manifestação ao passar a imagem de que as pessoas são impedidas de exercer o direito de ir e vir e, com tudo isso, seu objetivo final é desconstruir a resistência.

A tentativa de criminalizar a manifestação se mostra mais nítida no meme seguinte. Aqui o autor afirma, de forma explícita, que os manifestantes são vagabundos que causam o terrorismo nas cidades ao impedir os cidadãos de se locomover. Como no meme anterior, temos aqui metáforas orientacionais que desqualificam o movimento comparando-o com fracasso e terror. Temos também metáforas ontológicas ao personificar a greve como entidade humana representada pelo termo "a greve fracassou". No entanto, o que se mostra mais enfático é o uso da metáfora estrutural GREVE É TERRORISMO. Nesse caso, o autor utiliza um conceito bem estruturado e reconhecido pelo público em geral como terrorismo para convencer sua audiência da nocividade da greve para os cidadãos transeuntes impedindo-os de se locomover.

Figura 6 - Meme Coxinha 4 sobre Greve Geral

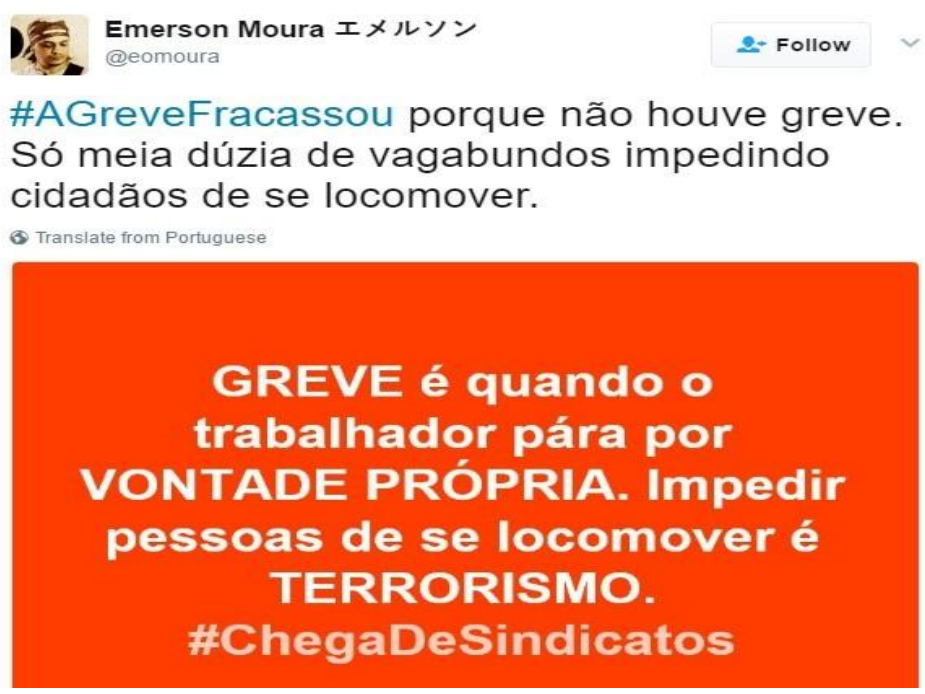

Fonte: Google Imagens.

São construídos pelo autor os seguintes conceitos metafóricos: GREVE É VAGABUNDAGEM, GREVE É CAOS, GREVE É FRACASSO, SINDICALISMO É FRACASSO, GREVE É TERRORISMO. Seus objetivos são dividir a classe trabalhadora, depreciar a greve, criminalizar a manifestação, desconstruir a resistência e desmontar o sindicalismo, algo nítido ao propor a hashtag ChegaDeSindicalismo. 
O último meme coxinha analisado foi postado pelo prefeito de São Paulo, Dória, dois dias antes da Greve Geral e minutos depois foi replicado milhares de vezes. Sua postagem foi considerada por muitos uma afronta ao direito de manifestação e de greve, uma vez que apresentava um forte apelo para a desmobilização.

Figura 7 - Meme Coxinha 5 sobre Greve Geral

\section{(D) Salvar oäo Doria@@ @joriajr-Apr 26 \\ Sexta-feira, 28 de abril de 2017, será dia de trabalho! Mais um dia para \\ construirmos um pais digno e honrado. Quem ama o Brasil, trabalha!}

6. Translate from Portuguese

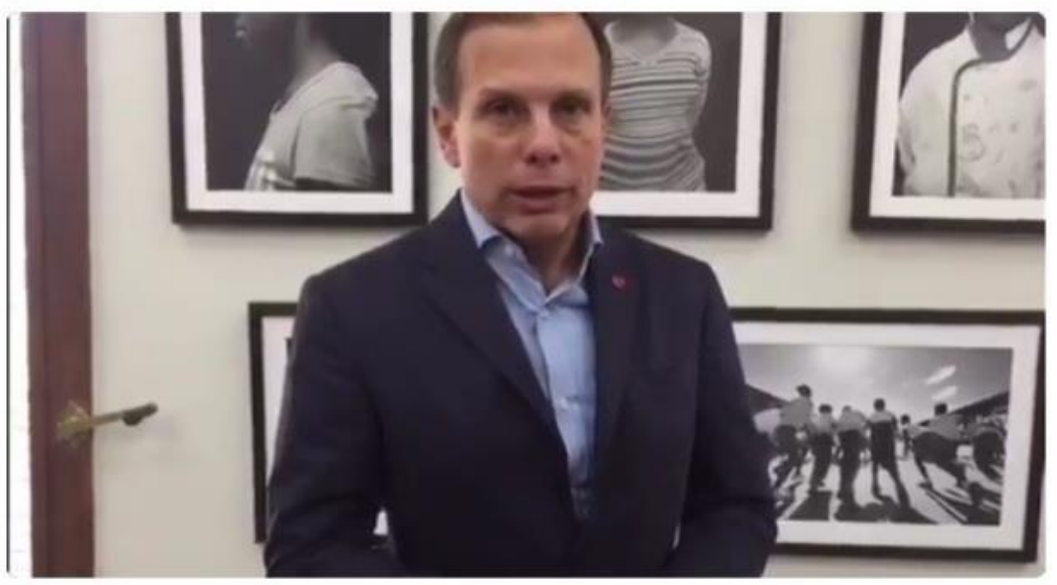

Fonte: Google Imagens.

Temos aqui um exemplo de metáfora orientacional que busca construir um mapa conceitual no qual aqueles que aderirem à greve demonstrarão indignidade e desonra. Assim, parar um dia de trabalho significa, para o prefeito, um ato de desamor à pátria. Nesse sentido, identificamos o seguinte mapa conceitual metafórico: TRABALHAR É SER DIGNO E HONRADO, TRABALHAR É AMAR O PAÍS, GREVE É INDIGNA E DESONROSA, GREVE É NÃO AMAR O PAÍS. Esse mapa conceitual objetiva, dentre outras intencionalidades, realizar a divisão da classe trabalhadora demonstrando que o correto é trabalhar em prol do país. Objetiva-se, assim, depreciar a greve e desconstruir a resistência. A seguir, apresentaremos as análises realizadas sobre os memes mortadela. 


\section{Memes mortadela}

0 primeiro meme mortadela busca representar as consequências dicotômicas das reformas trabalhistas, um dos pontos motivadores da greve geral, para empregados e patrões. Para tanto, o autor utiliza imagens do cantor Chico Buarque mostrando duas expressões faciais opostas. A primeira imagem alude à nocividade das reformas para os trabalhadores, representada pela expressão de descontentamento. Já a segunda imagem denota as intenções das reformas como favoráveis aos patrões, o que se representa pela expressão facial de contentamento.

Figura 8 - Meme mortadela 1 sobre a Greve Geral

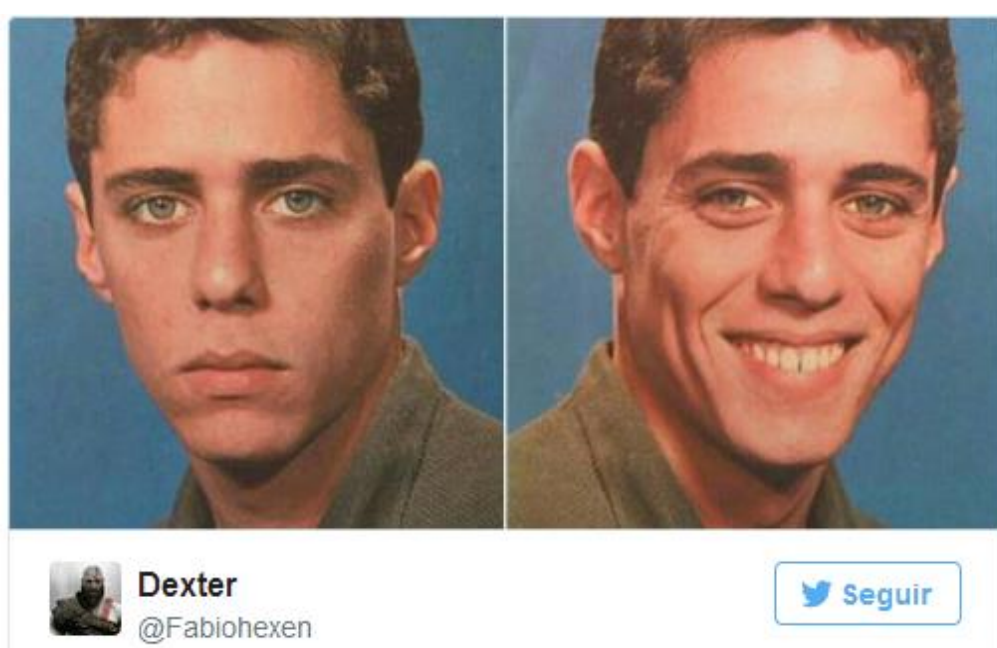

Sobre alguns pontos que pude observar na \#ReformaTrabalhista

Empregado/Patrão

12: 25 - 27 Apr 2017 - Rio Branco, Brazil

4 $น 72$

Fonte: Google Imagens.

Desse modo, identificamos facilmente o uso de metáfora orientacional sendo empregados os conceitos metafóricos REFORMA É TRISTEZA (PARA O EMPREGADO), REFORMA É ALEGRIA (PARA O PATRÃO).

Diferentemente dos memes coxinhas que tinham a intenção principal de atacar os adversários, nesse meme, e nos demais apresentados a seguir, os objetivos eram conscientizar os trabalhadores sobre a importância da greve, apontar contradições existentes entre os interesses motivadores das reformas e mobilizar a classe trabalhadora para participar das manifestações. 
O segundo meme mortadela apresenta uma imagem de um carro com uma frase que alude a uma passagem bíblica, um mandamento ou mesmo uma mensagem apocalíptica na qual o mensageiro seria o próprio Presidente do Brasil, responsável pelas políticas de austeridade. Aqui percebemos a presença de metáfora orientacional posicionando as reformas negativamente e metáfora estrutural na medida em que o autor utiliza algo bem presente no cotidiano popular, as passagens bíblicas, para explicar e fazer a audiência compreender algo complexo e danoso como as reformas em andamento.

Nesse sentido, é construído o mapa conceitual REFORMA É CRUELDADE, REFORMA É APOCALIPSE para explicar de forma mais acessível os prejuízos que tais reformas podem trazer para a classe trabalhadora. Portanto, os objetivos do meme são conscientizar os trabalhadores sobre o perigo das reformas e apontar as contradições existentes no jogo de interesses por detrás das políticas de austeridade em implementação. Há também o interesse de ironizar a hashtag contrária à greve eu vou trabalhar. No entanto, diferentemente dos memes coxinhas, a ironia apresenta argumentos que demonstram a necessidade de adesão ao movimento. Já no caso dos memes coxinhas a intenção era simplesmente desmobilizar a resistência maculando a imagem das entidades organizadoras.

Figura 9 - Meme mortadela 2 sobre a Greve Geral

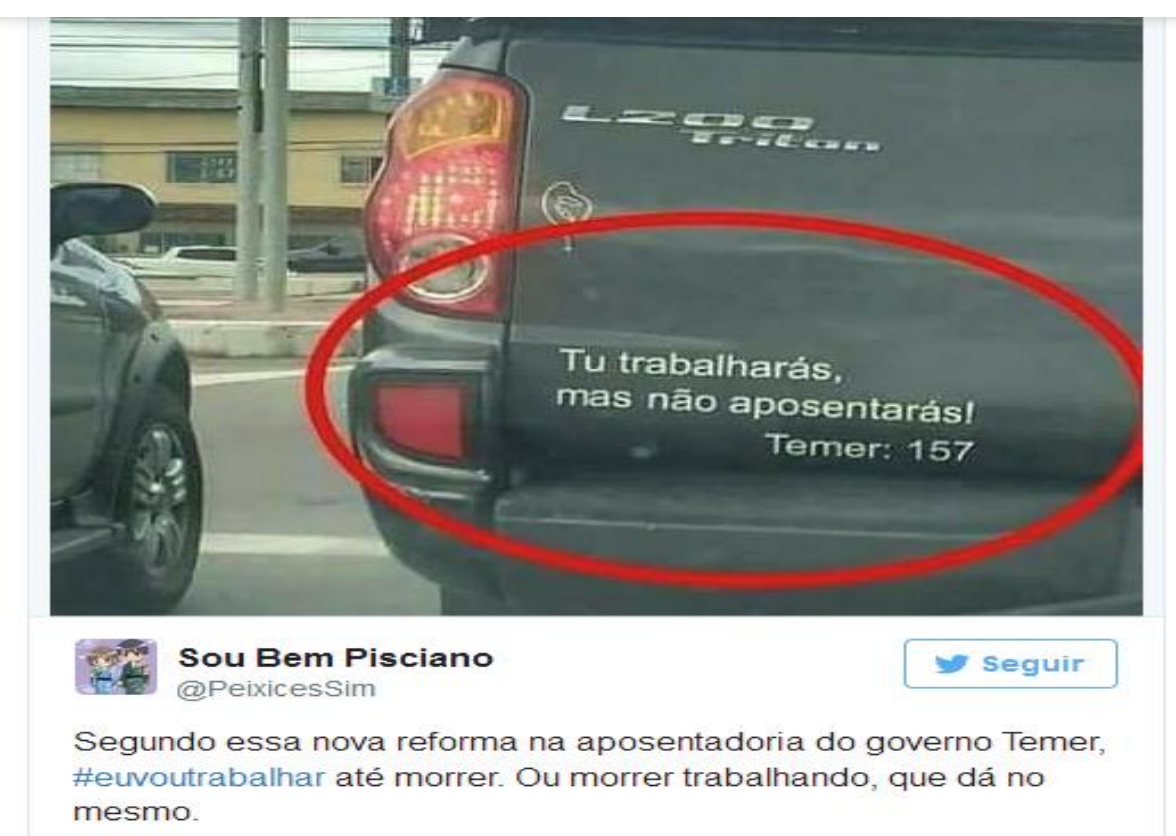

Fonte: Google Imagens. 
O próximo meme mortadela apresentava a imagem da entrada do principal campo de concentração nazista na Polônia. Aqui há um forte apelo para desqualificar aqueles que poderiam deixar de participar da greve aderindo à hashtag euvoutrabalhar.

Figura 10 - Meme mortadela 3 sobre a Greve Geral
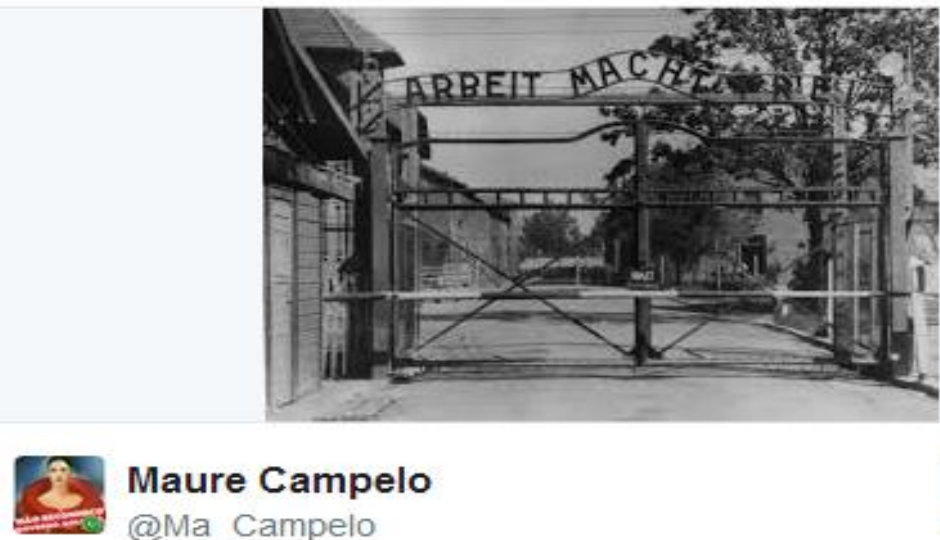

Maure Campelo

@Ma_Campelo

Seguir

essa hastag \#euvoutrabalhar me lembrou da inscrição na entrada de Auschwitz: "Arbeit macht frei" ou "o trabalho te liberta"

15: 52 - 28 Apr 2017

4 4764

88

Fonte: Google Imagens.

Nesse sentido, utiliza-se um símbolo das maiores barbáries humanas (o holocausto) para conscientizar os trabalhadores sobre o erro que é permitir ser persuadido por um artifício que, assim como ocorreu com os judeus, tenta convencer as pessoas a se entregarem ao sacrifício do trabalho até a morte. Assim, temos uma metáfora orientacional que desqualifica o movimento contrário à greve e uma metáfora estrutural que tenta conscientizar os trabalhadores sobre os riscos das reformas comparando-as ao holocausto.

Nessa lógica, identificamos as metáforas conceituais FURAR GREVE É RESIGNAÇÃO, GREVE É RESISTÊNCIA, HASTAG É INSTRUMENTO DE MANIPULAÇÃO, REFORMA É CRUELDADE. Tais conceitos buscam conscientizar os trabalhadores sobre a necessidade de resistência e apontar contradições de interesses.

O quarto meme mortadela traz a imagem de um personagem animado, um dinossauro de fisionomia assustadora, conhecido por ser um patrão cruel que literalmente come seus empregados que de alguma forma tentam lhe questionar. 
Figura 11 - Meme mortadela 4 sobre a Greve Geral

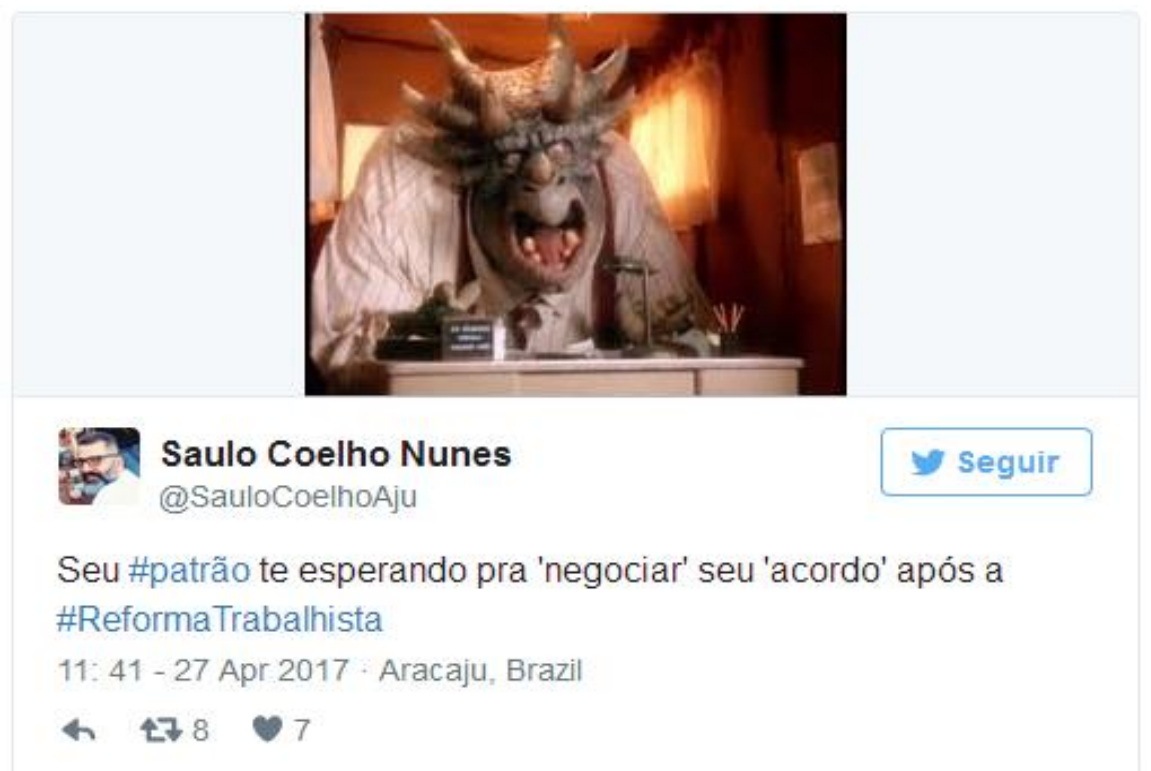

Fonte: Google Imagens.

O tema central desse meme é construído para questionar o argumento utilizado pelo Governo para convencer a população de que a reforma irá favorecer a livre negociação entre empregados e patrões. 0 autor busca representar a desproporcionalidade de poder entre os lados opostos da relação trabalhista. Para tanto, utiliza uma metáfora orientacional, localizando a força do patrão para cima e a força do empregado para baixo. Utiliza ainda metáfora ontológica, personificando um ser não humano. Ainda há metáfora estrutural ao utilizar um personagem bem popularizado e com características bem marcantes para explicar a desproporção de forças entre lados antagônicos e, com isso, mobilizar os trabalhadores a impedir o avanço das reformas.

São empregados os seguintes conceitos metafóricos: PATRÃO É CONTROLADOR DO PODER, PATRÃO É INIMIGO, NEGOCIAÇÃO É INJUSTIÇA. De tal maneira, o autor do meme objetiva conscientizar os trabalhadores sobre a impossibilidade de negociação diante de assimetria de poder e apontar contradições nessa relação e nos interesses de empregados e patrões.

O último meme analisado apresenta a imagem de duas vacas reclamando sobre o possível atraso que poderiam sofrer ao tentar chegar ao trabalho por conta das manifestações. No entanto, em uma alusão à possibilidade de ter que trabalhar até a morte, a imagem mostra o local de trabalho dos animais: um matadouro. Com isso, o autor critica àqueles que se concentram em chegar ao serviço e não se dão conta dos 
riscos que as reformas podem trazer para as garantias trabalhistas como o direito à aposentadoria.

Figura 12 - Meme mortadela 5 sobre Greve Geral

Julio Cézar Queiróz

@comunacritico

E a galera do \#euvoutrabalhar preocupada como chegar no trabalho indo direto pro matadouro...

\section{\#BrasilEmGreve}

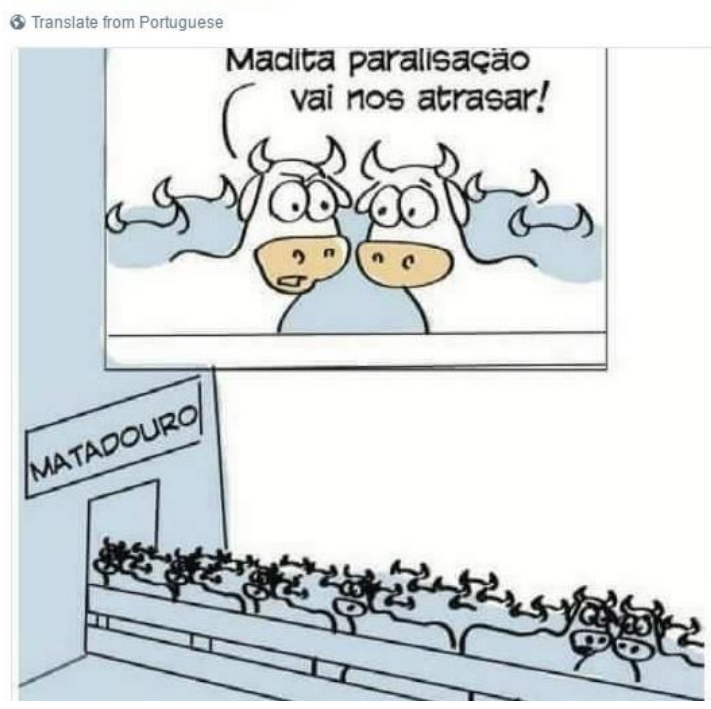

Fonte: Google Imagens.

Nesse meme, encontramos também os três tipos de metáforas conceituais. A metáfora orientacional apresenta a reprovação daqueles que se posicionam a favor de furar a greve. A metáfora ontológica personifica animais, comparando a atitude de pessoas que não resistem aos ataques aos seus direitos, à postura irracional de animais que são incapazes de questionar as situações de exploração à qual são assujeitados. E, por fim, a metáfora estrutural busca explicar algo bastante complexo como a implementação de reformas que podem condenar os trabalhadores à labuta perpétua utilizando algo bem estruturado na mente da população que é o sacrifício de animais para consumo humano.

Nesse meme, são elaborados os seguintes conceitos metafóricos: REFORMA É MASSACRE, TRABALHADOR APOIAR REFORMA É SUICÍDIO. Com isso, o autor pretende conscientizar os trabalhadores sobre a necessidade de resistência e, novamente, apontar as contradições existentes entre os interesses de trabalhadores e reformistas.

Após essas análises, apresentaremos algumas considerações importantes que podem indicar o modo como as escolhas de conceitos metafóricos indiciam os 
posicionamentos políticos e sociais de autores de memes. De tal forma, após realizar as análises que permitiram observar separadamente cada postagem, realizaremos uma síntese, configurando cada grupo de memes diante dos conceitos metafóricos escolhidos e dos objetivos pretendidos.

\section{Algumas considerações importantes e implicações do estudo}

Primeiramente é necessário considerar a nítida divisão dos memes em dois grupos antagônicos que aqui denominamos de coxinhas e de mortadelas. Apesar de as postagens pertencerem a autores distintos, os integrantes de cada grupo apresentaram mapas conceituais metafóricos bastante similares intragrupo (entre os membros do mesmo grupo) e muito opostos intergrupo (entre membros de grupos contrários), marcando bem as diferenças de escolhas realizadas e de objetivos pretendidos.

Ficou nítido, também, o fato de que cada tipo de metáfora empregada tinha um objetivo a depender do grupo ao qual pertencia a postagem. Assim, de modo geral, os memes coxinhas utilizavam metáforas orientacionais posicionando a greve como negativa (vagabundagem, caos, indignidade, desonra e desamor ao país) e, buscando desqualificar, orientar para baixo, os manifestantes de forma bastante agressiva e ofensiva. Em oposição, os memes mortadelas utilizavam metáforas orientacionais posicionando os interesses dos patrões como negativos para a classe trabalhadora e dos empregados como positivos e posicionando o poder dos patrões como alto e dos empregados como baixo.

Em relação ao uso de metáforas ontológicas, percebemos que os memes coxinhas as empregavam para culpabilizar os organizadores (tomando a parte CUT/PT como o todo centrais sindicais) pelo suposto fracasso da greve e o caos que ela causou. Já os memes mortadelas utilizaram esse tipo de metáfora para representar assimetria de poder entre patrões e trabalhadores sinalizando a impossibilidade de negociação diante de forças não compatíveis.

Quanto à escolha de metáforas estruturais, percebemos que o quarto meme coxinha (Figura 6) emprega essa forma de metáfora para convencer a audiência de que a greve, por meio de atos de alguns poucos manifestantes, não passa de um ato criminoso que deve ser repudiado ao mesmo nível em que se repudia o terrorismo. De outra forma, os memes mortadelas utilizam metáforas estruturais como forma de conscientizar os 
trabalhadores sobre os riscos da reforma para os direitos trabalhistas conquistados (crueldade, apocalipse).

Com tudo isso, podemos concluir que os dois grupos expressam opiniões que podem ser percebidas em campos distintos de ações. Nesse sentido, os memes coxinhas demonstram um notório (às vezes implícita, às vezes explicitamente) conteúdo partidarista por meio das metáforas conceituais por eles escolhidas para opinar sobre o tema Greve Geral que podem se resumir em: MANIFESTAÇÃO É CUT/PT. Com isso, os autores associam tudo de ruim à greve (CAOS, FRACASSO, BURRICE, TERRORISMO, INDIGNIDADE, DESONRA, NÃO AMAR O PAÍS) maculando, dessa forma, a imagem de determinado partido político. Essa conclusão pode ainda ser reforçada ao observar de onde partem tais memes (\#MoroBrasilTe Apoia, \#ChegaDeSindicalismo e do prefeito do PSDB João Dória).

Já as escolhas dos memes mortadelas demonstram um conteúdo classista que enxerga na luta de classes a forma de resistir aos ataques aos direitos trabalhistas se opondo às políticas de austeridade e àqueles que não querem participar do manifesto. Assim, os conceitos metafóricos apontam as reformas de forma negativa (TRISTEZA, CRUELDADE, APOCALIPSE, MANIPULAÇÃO, INJUSTA, MASSACRE), conceitua a greve como forma de resistência (RESISTÊNCIA) e repudia aqueles que não aderiram ao manifesto (RESIGNAÇÃO, SUICÍDIO).

Percebemos que os grupos se utilizam das metáforas com estratégias distintas. Dessa maneira, os memes coxinhas utilizam orações referenciais aos outros (os grevistas) buscando desqualificar as ações, mas não apresentam contrapropostas e não se posicionam quanto à legitimidade da greve. Para eles, o importante é construir a compreensão, simplesmente desqualificando a resistência, de que não é uma boa ideia aderir à greve. O foco é impedir a ação e não discutir os objetivos dessa ação. Em contrapartida, os memes mortadelas posicionam-se enaltecendo suas ações em busca de mudanças político-sociais. O foco é na ação como meio para atingir o objetivo de resistir às reformas.

Em relação à estrutura dos memes, percebemos que eles são estruturados por meio de um encadeamento lógico e intencional de conceitos que permitem persuadir e construir uma opinião bem estruturada sobre fatos sociais. Assim, são construídos verdadeiros silogismos matematicamente estruturados ( $\mathrm{Se} A=B, B=C, E N T A \tilde{O}, A=C$ ) ou (Se $A=B, B \neq C$, então $A \neq C)$. A seguir reproduzimos um desses silogismos para uma maior compreensão daquilo que estamos expondo: 
Figura 13 - Silogismo metaforicamente construído

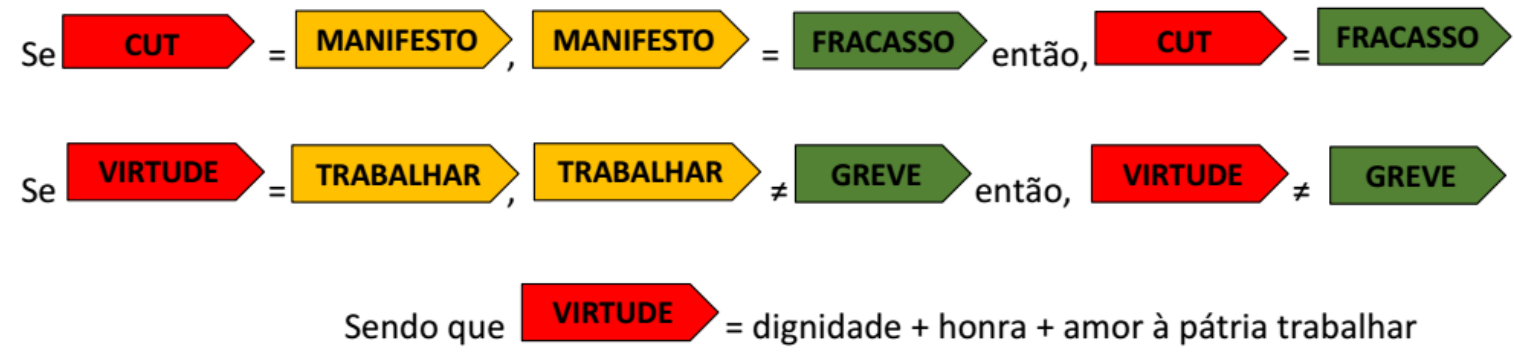

Fonte: $\mathrm{O}$ autor.

Importante destacar que, em um silogismo condicional desse tipo, o termo A é suficiente para o termo B. Isso implica o fato de que, a simples presença da CUT é suficiente para a realização de manifestos, e ainda, de fracasso.

Consideramos, ainda, que o estudo dos memes pode ajudar a levantar pistas que podem subsidiar a compreensão dos fenômenos sociais, uma vez que existem memes sobre variados aspectos da vida cotidiana. Como observamos na presente pesquisa, os memes não são apenas uma forma divertida de encarar os fatos sociais. As informações que carregam e as ideias que propagam podem fornecer indícios sobre os sistemas conceituais em jogo, as contradições em cena e as preferências político-sociais dos agentes. Nesse sentido, um meme pode dizer muito mais a respeito de quem o produziu e de quem o compartilha nas redes sociais do que uma confissão explícita expressa em texto com linguagem direta.

Por fim, destacamos como mais a importante implicação desse estudo a consideração dos memes muito além de inocentes postagens engraçadas sobre algum tema. Em verdade, são poderosas armas de formação de opiniões e de manipulação dos fatos sociais, ou seja, cumprem com maestria seu papel ideológico. Nossa intencionalidade em estudá-los é demonstrar que eles podem cumprir um importante papel na "luta para remoldar as práticas discursivas e as ideologias nelas construídas no contexto da reestruturação ou da transformação das relações de dominação" (FLARCLOUGH, 2001, p. 117).

Desse modo, ao serem replicadas simplesmente porque foram consideradas engraçadas pode-se cometer um erro muito perigoso para as garantias sociais conquistadas. Isso porque, quanto mais circulam entre as redes sociais, mais vão se configurando como verdades incontestáveis, tendo em vista que "as ideologias 
embutidas nas práticas discursivas são muito eficazes quando se tornam naturalizadas e atingem o status de senso comum" (FLARCLOUGH, 2001, p. 117). E com a replicação automática e sem criticidade, cumpre-se a lei que o abominável ministro da propaganda nazista Joseph Goebbels (1897-1945) instituiu: uma mentira repetida mil vezes se torna verdade.

\section{Referências}

BENTO, J. D.; SILVA, F. C. Metáforas visuais em textos multimodais em textos: análise de textos de provas do Enem. Revista Letra Capital, v. 1, n. 1, p. 116-140, jan./jun. 2016.

CANNON-BOWERS, J. A.; SALAS, E. Reflections on shared cognition. Journal of Organizational Behavior, v. 22, n. 2, p. 195-202, 2001.

DAWKINS, R. O Gene Egoísta. Tradução de Geraldo H. M Florsheim. Belo Horizonte/MG: Itatiaia Limitada, 1979.

DIJK, T. A. V. Discurso e contexto: uma abordagem sociocognitiva. São Paulo: Contexto, 2012.

FAIRCLOUGH, N. Discurso e mudança social. Tradução de. Brasília. Tradução de Izabel Magalhães. Brasília: Universidade de Brasília, 2001.

LAKOFF, G. A figure of thought. Metaphor and symbolic activity, v. 1, n. 3, p. 215-225, 1986.

LAKOFF, G.; JOHNSON, M. Metáforas da vida cotidiana. Campinas: Mercado de letras, 2002.

LAKOFF, G.; JOHNSON, M. Metafors we live by. Chicago: University of Chicago Press, 1980.

SILVA, D. E. G. D. Metáforas sob a lupa da Análise de Discurso Crítica. In: SILVA, D. E. G. D. língua, gramática e discurso. Goiânia: : Cânone Editorial/Grupo de estudos de linguagem do centro oeste, 2006. p. 161-178. 

v. 3 (1), p. $167-196.2018$ 